\title{
Fuel properties and emission characteristics of biodiesel produced from unused algae grown in India
}

\author{
Rachan Karmakar $^{1} \cdot$ Krishnendu Kundu $^{2}$ - Anita Rajor ${ }^{1}$
}

Received: 1 May 2017 / Published online: 23 December 2017

(C) The Author(s) 2017. This article is an open access publication

\begin{abstract}
The high price of different biodiesels and the need for many of their raw ingredients as food materials are the main constraints to be overcome when seeking the best potential alternative fuels to petro-diesel. Apart from that, some properties like high density, viscosity and acid value along with low cloud and pour points preclude their use in compression ignition (CI) engines as these properties can cause serious damage to the parts of the engine and reduce engine life. In this experiment, biodiesel was produced from the oil of unused algae by a two-step 'acid esterification followed by transesterification' procedure. Taguchi's method was applied to design the experiment, and a L25 orthogonal array was prepared to optimize the biodiesel production procedure. The optimized conditions for transesterification were: methanol to oil molar ratio of 6:1, catalyst $(\mathrm{KOH})$ concentration of $2.5 \mathrm{wt} \%$, reaction time of $90 \mathrm{~min}$ and reaction temperature of $50{ }^{\circ} \mathrm{C}$, achieving a biodiesel production of $89.7 \%$ with free fatty acid content of $0.25 \%$. It was found that the CI engine emitted less $\mathrm{CO}, \mathrm{CO}_{2}$ and hydrocarbon and higher $\mathrm{NO}_{x}$ using algal biodiesel than that using petro-diesel. All properties of the algal biodiesel were within the limit of ASTM standards.
\end{abstract}

Keywords Algae $\cdot$ Biodiesel $\cdot$ Fuel characterization $\cdot$ Emission

\section{Introduction}

Biodiesels from different sources, like vegetable oil (Gadge and Raheman 2005; Alcantara et al. 2000; Ragit et al. 2011) and animal fat (Bankovic-llic et al. 2014; Adewale et al. 2015), have become popular over the last few years. Although the main constraints of applications of biodiesels are their high market price (Amano-Boadu et al. 2014) and need for many of their feedstock as food resources, the other important factor to restrict them from being used more is that they can damage the engine parts due to some of their properties and thereby reduce the engine life. The threats of pollution due to the use of conventional and nonconventional fuels are becoming evident (Conti and

Edited by Xiu-Qin Zhu

Rachan Karmakar

rachan.in.air@gmail.com

1 School of Energy and Environment, Thapar University, Patiala, Punjab 147004, India

2 Department of Biofuel, CSIR CMERI CoEFM, Ludhiana, Punjab 141006, India
Holtberg 2011). It is found that biofuels including biodiesels are more eco-friendly than petro-diesel (Shirneshan et al. 2012; An et al. 2012; Shirneshan 2013). Only the $\mathrm{NO}_{x}$ emission from the combustion of biodiesels has been reported to be more than that of petro-diesel (Xue et al. 2011). From the point of view of environmental pollution, algae can be a good resource for biodiesel production. It has been reported that application of air supplemented with carbon dioxide at the time of algae culture increases the oil content of the algae (Holbrook et al. 2014; Dassey et al. 2014) and biofuels from algae fix $0.6 \% \mathrm{CO}_{2}$ (Ponnusamy et al. 2014).

Different types of algae are seen to grow widely in various types of medium. Barren, non-productive land (Costa and Moraise 2011), brackish water and waste water (Ashokkumar et al. 2014) can be used to culture some of the algal species. On top of that, the oil content and the growth rate of the algae are also very high (Chisti 2007, 2008) compared to many other crops that are used for biodiesel production. In this study, cultures of algae from different canals in Punjab (India) were used as the feedstock for production of biodiesel, for the following reasons. These algae (1) remain unused and taken away followed by 
being thrown in vats (which are used for waste disposal) and dumped in waste disposal sites at the end, (2) cause pollution of the water-body when growing very abundantly and become a threat to aquatic life and (3) are not used as food. The aim of this research was to characterize the fatty acid methyl ester (FAME) produced from the oil of those unused algae with standard methods (Ragit et al. 2012) and to study the emission characteristics of the fuel by running a CI engine with that biodiesel.

\section{Materials and methods}

\subsection{Biodiesel production from unused algae}

The algal culture was collected from several canals of Punjab, India. Many times in a year, especially in winter, the current of the canals remains very low or it becomes stagnant. Eutrophication and algal blooms take place in these water bodies during these times due to immobilization of the nutrient. These algae degrade naturally with time or flow away when the current of the water increases. Sometimes this mixed culture of algae is thrown in vats which are used for the disposal of wastes. So, these algae are treated as wastes and remain unused. This mixed culture of algae (Closterium sp., Chlorella sp., Oscillatoria sp., Spirulina sp., Navicula sp., Pinnularia sp., Spyrogyra sp., Gomphonema sp., Scenedesmus sp., Zygnema sp. and Frustulia sp.) was collected from their sites for this experiment and kept in the sun for seven days for complete drying. Extraction of oil from the dry algae was done by solvent extraction using a SOXTHERM apparatus (Fernández et al. 2010; Silva et al. 2011), and $n$-hexane was used as a solvent (Karmakar et al. 2018). All the samples of algae were ultrasonically treated before use. Almost $10 \%$ oil was extracted in this procedure. A two-step procedure, which is a combination of acid esterification and alkali achieving lowest FFA along with highest yield was set as the goals for the alkali-esterification reaction.

The best result for acid esterification took place when the reaction was performed with combination 17 (Fig. 1a). The FFA content of the oil came down from $21 \%$ to $1.7 \%$ after acid esterification. The product was kept inside a hot air oven for $1 \mathrm{~h}$ at $100{ }^{\circ} \mathrm{C}$ after which it underwent alkali esterification. This time combination 13 was found to be most effective to produce algal biodiesel with highest yield and lowest FFA content (Fig. 1b(i) and b(ii)). The amount of ester produced in this procedure was $89.7 \%$, while the FFA content of the biodiesel was $0.25 \%$. The presence of different fatty acid methyl esters was detected by gas chromatography-mass spectrometry (GC-MS). The composition of the biodiesel is given in Table 2 .

\subsection{Properties of the biodiesel}

The properties of the biodiesel give an indication of whether it would be suitable or not for the performance, life and emission of the engine. So, the main properties of biodiesel such as the acid number, calorific value, viscosity, density, flash point, fire point, cloud point, pour point, ash content and carbon residue content (Karmakar et al. 2018) were studied using standard methods (Table 3). Three replications were done for all the tests, and their means were calculated.

\subsubsection{Acid number}

The titration method was used to estimate the acid number of the biodiesel. A $0.1-0.5 \mathrm{~mL}$ of biodiesel was taken in a conical flask. A $50 \mathrm{~mL}$ of solvent mixture $(95 \%$ ethanol and diethyl ether in 1:1 ratio) was added to it and mixed thoroughly. This solvent-oil mixture was titrated with $0.1 \mathrm{M} \mathrm{KOH}$ using $1 \%$ phenolphthalein indicator. The formula for calculating acid number is as follows:

Acid number of biodiesel $(\mathrm{mg} \mathrm{KOH} / \mathrm{g})=\frac{56.1 \times \text { Normality of the } \mathrm{KOH} \text { solution } \times \text { Volume of } \mathrm{KOH} \text { used }}{\text { Weight of the sample taken }}$

esterification, was used in this experiment for biodiesel production (Sumit et al. 2016). Taguchi's method (Buasri et al. 2009; Ross 1989; Kumar et al. 2017) was used to prepare twenty-five sets (orthogonal L25 array) of parameters (reaction temperature, methanol to oil molar ratio, catalyst concentration and reaction time) for both esterification procedures (Table 1). In the acid esterification reaction, achieving the lowest FFA was set as the target but

\subsubsection{Calorific value (CV)}

A bomb calorimeter (Widsons) was used to measure the calorific value (Ragit et al. 2011) of the algal biodiesel. The biodiesel $(0.5 \mathrm{~g})$ in a container was placed in the bomb, and a 8-cm cotton thread hanging from an 8-cm nichrome wire was dipped into the biodiesel. The bomb was filled with oxygen at $400 \mathrm{psi}$. Then, it was placed inside the insulated container containing distilled water and the fuse wires were 
Table 125 combinations of parameters used for optimization of algal biodiesel production procedure (designed by Taguchi's statistical approach (Ross 1989; Buasri et al. 2009))

\begin{tabular}{|c|c|c|c|c|}
\hline Combination no. & Methanol to oil molar ratio & Catalyst concentration, wt $\%$ & Reaction time, min & Reaction temperature, ${ }^{\circ} \mathrm{C}$ \\
\hline 1 & $4: 1$ & 1.5 & 30 & 45 \\
\hline 2 & $4: 1$ & 2.0 & 45 & 50 \\
\hline 3 & $4: 1$ & 2.5 & 60 & 55 \\
\hline 4 & $4: 1$ & 3.0 & 75 & 60 \\
\hline 5 & $4: 1$ & 3.5 & 90 & 62 \\
\hline 6 & $5: 1$ & 1.5 & 45 & 55 \\
\hline 7 & $5: 1$ & 2.0 & 60 & 60 \\
\hline 8 & $5: 1$ & 2.5 & 75 & 62 \\
\hline 9 & $5: 1$ & 3.0 & 90 & 45 \\
\hline 10 & $5: 1$ & 3.5 & 30 & 50 \\
\hline 11 & $6: 1$ & 1.5 & 60 & 62 \\
\hline 12 & $6: 1$ & 2.0 & 75 & 45 \\
\hline 13 & $6: 1$ & 2.5 & 90 & 50 \\
\hline 14 & $6: 1$ & 3.0 & 30 & 55 \\
\hline 15 & $6: 1$ & 3.5 & 45 & 60 \\
\hline 16 & $7: 1$ & 1.5 & 75 & 50 \\
\hline 17 & $7: 1$ & 2.0 & 90 & 55 \\
\hline 18 & $7: 1$ & 2.5 & 30 & 60 \\
\hline 19 & $7: 1$ & 3.0 & 45 & 62 \\
\hline 20 & $7: 1$ & 3.5 & 60 & 45 \\
\hline 21 & $8: 1$ & 1.5 & 90 & 60 \\
\hline 22 & $8: 1$ & 2.0 & 30 & 62 \\
\hline 23 & $8: 1$ & 2.5 & 45 & 45 \\
\hline 24 & $8: 1$ & 3.0 & 60 & 50 \\
\hline 25 & $8: 1$ & 3.5 & 75 & 55 \\
\hline
\end{tabular}

placed in their position on the bomb. The nichrome wire was stuck to two sticks attached to the fuse wires. The initial temperature was noted, and then it was reduced to zero $\left(0{ }^{\circ} \mathrm{C}\right)$. The fire button was pressed to make a short circuit on the nichrome wire and ignite the biodiesel. The temperature kept on increasing for a certain time. The temperature was noted when it was stable. The calorific value was then calculated using the following formula. placed underneath. As $50 \mathrm{~mL}$ of the biodiesel was collected in the measuring cylinder, the stopper was placed again to stop the flow of the biodiesel. The time taken for the collection of $50 \mathrm{~mL}$ biodiesel was noted. The formula to calculate the viscosity of the biodiesel is as follows:

Viscosity of biodiesel $\left(\mathrm{mm}^{2} / \mathrm{s}\right)=(A \times$ time $)-\frac{B}{\text { time }}$

$\mathrm{CV}(\mathrm{kJ} / \mathrm{kg})=\frac{(\text { Weight of water }+ \text { water equivalent }) \times \text { Temperature rise } \times \text { Specific heat of water }}{\text { Weight of the sample }}$

\subsubsection{Kinematic viscosity}

The biodiesel was poured into the heat chamber of a Redwood viscometer and heated up to $40{ }^{\circ} \mathrm{C}$. The stopper of the viscometer was displaced to let the heated biodiesel drain out of it and be collected in a measuring cylinder where $A$ and $B$ are two constants for the specific Redwood viscometer. $A=0.26$ and $B=179$ (when the time taken is less than $100 \mathrm{~s}$ ), or $A=0.24$ and $B=50$ (when time taken is more than $100 \mathrm{~s}$ ). 
(a)

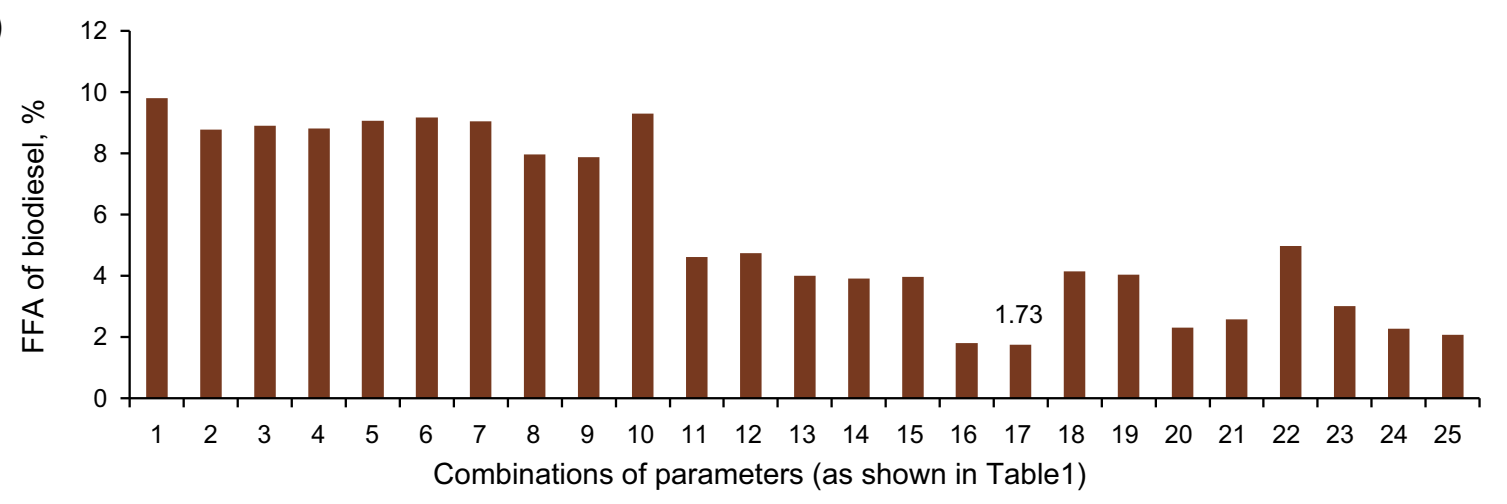

(b-i)

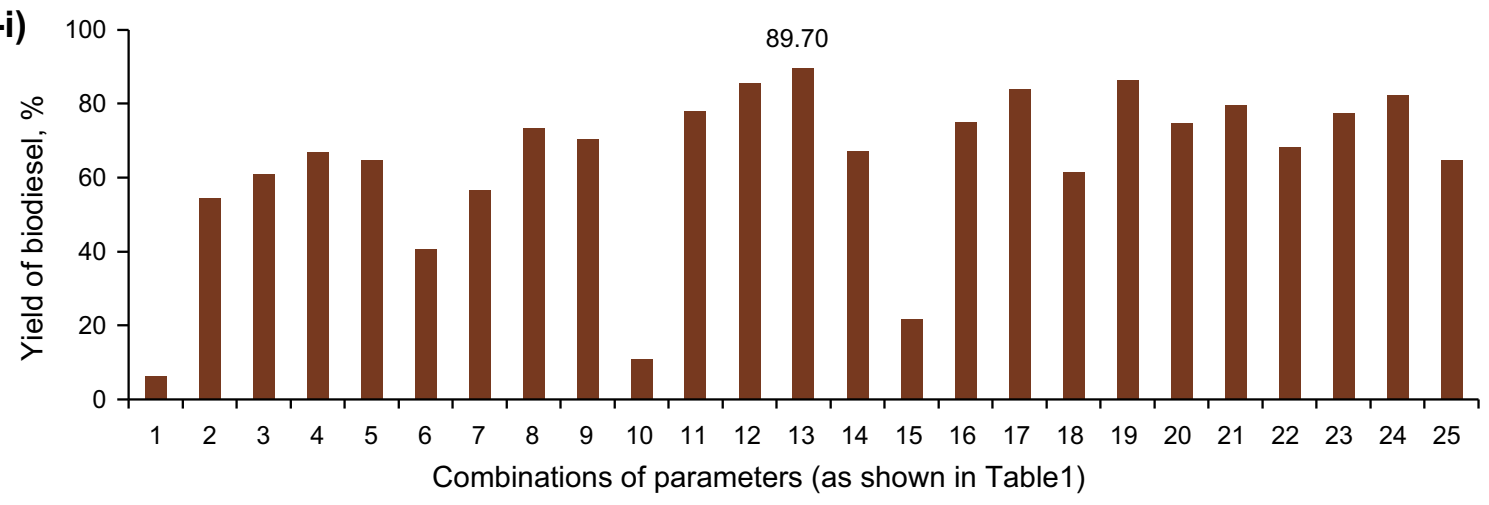

(b-ii)

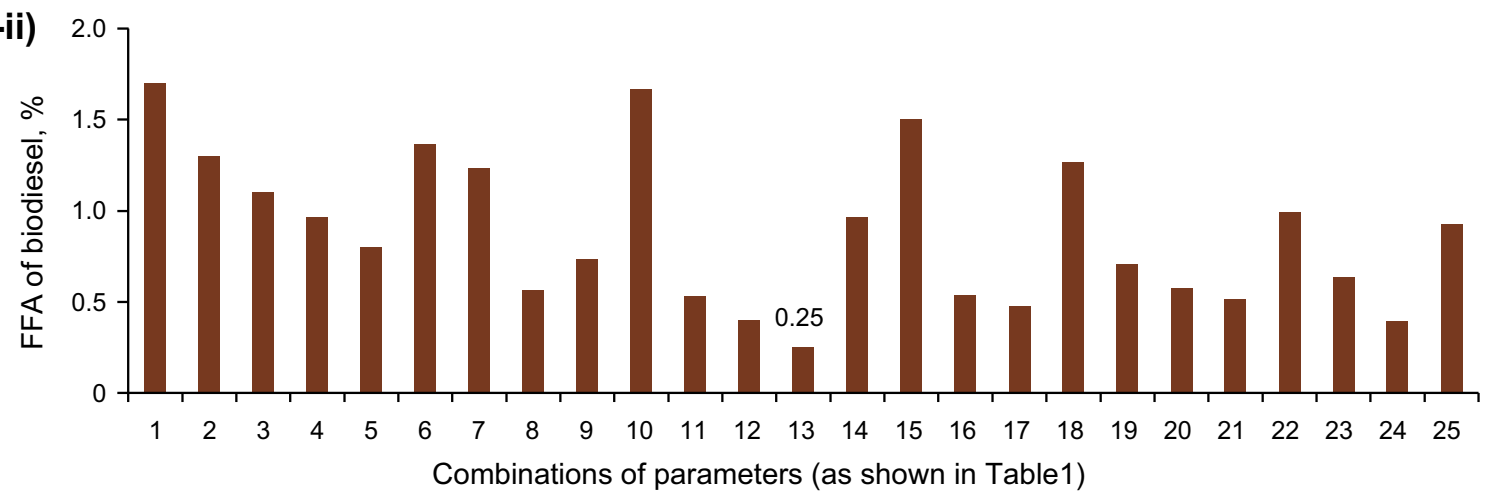

Fig. 1 Effect of different combinations of parameters on biodiesel production. a acid esterification (effect on FFA content) and b alkali esterification-b(i) effect on yield; $\mathbf{b}($ ii) effect on FFA content

Table 2 Fatty acid composition of algal biodiesel

\begin{tabular}{llc}
\hline No. & Fatty acid & Percentage \\
\hline 1 & Palmitic & 9.69 \\
2 & Stearic & 0.02 \\
3 & Oleic & 2.34 \\
4 & Linoleic & 54.33 \\
5 & Linolenic & 8.71 \\
6 & Others & 24.91 \\
\hline
\end{tabular}

\subsubsection{Relative density (D)}

The pycnometer was kept inside a refrigerator after filling them up with algal biodiesel. They were taken out of the refrigerator when the temperature of the biodiesel reached $15^{\circ} \mathrm{C}$. The mass and volume of the biodiesel were measured, and the density of the biodiesel was calculated. The formula for measuring the density is as follows: 
$D\left(\mathrm{~kg} / \mathrm{m}^{3}\right)=\frac{\text { Mass of the pycnometer containing the biodiesel }- \text { Mass of the empty pyknometer }}{\text { Volume of the biodiesel }}$

\subsubsection{Flash and fire point}

The biodiesel was kept inside the flash and fire point apparatus, and a cotton thread was placed in it. The biodiesel was heated with a gas stove. Another ignited cotton thread was dragged on the surface of the former thread. The temperature at which the spark came out of first thread was noted as the flash point of the biodiesel, and the temperature at which the thread started burning was noted as the fire point of the biodiesel.

\subsubsection{Cloud and pour point}

The cloud and pour point apparatus was filled up with ice. The glass vessels of this apparatus, filled up with biodiesel, were placed in their slots of the apparatus. The temperature at which the paraffin in the biodiesel started solidifying and cloudiness appeared in the biodiesel was noted as the cloud point. The temperature at which the biodiesel becomes semi-solid was noted as the pour point of the algal biodiesel.

\subsubsection{Ash content}

The sample ( $5 \mathrm{~g}$ ) was taken in a pre-weighed quartz crucible and placed inside a muffle furnace (preheated at $450{ }^{\circ} \mathrm{C}$ ). After half an hour, when the biodiesel burnt completely to ash, the crucible was taken out. The crucible was weighed again when its temperature dropped to room temperature. The formula for calculating the ash content is given below.
Ash content of biodiesel (\%)

$\begin{aligned}= & \frac{\text { Initial weight of the crucible }- \text { Final weight of the crucible }}{\text { Weight of the biodiesel }} \\ & \times 100\end{aligned}$

\subsubsection{Carbon residue content}

The biodiesel ( $5 \mathrm{~g})$ was put inside a pre-weighed heat proof glass bulb and placed inside the carbon residue content apparatus (preheated at $450{ }^{\circ} \mathrm{C}$ ) and kept there for half an hour. The weight of the bulb was measured after its temperature dropped to room temperature.

Carbon residue content of biodiesel $(\%)$

$$
=\frac{\text { Initial weight of the bulb }- \text { Final weight of the bulb }}{}
$$

\subsection{Emission characteristics of the biodiesel}

The produced algal biodiesel (B100) and petro-diesel were used to run a CI engine (Table 4). A di-gas analyser (AVL 444) was used to check the emissions in the exhaust of the engine. The probe of the analyser was placed inside the exhaust, and the quantity of $\mathrm{CO}, \mathrm{CO}_{2}, \mathrm{NO}_{x}$, unburned hydro carbon (HC) was measured along with the exhaust temperature (measured with a thermometer) at different engine loads $(0 \%, 20 \%, 40 \%, 60 \%, 80 \%, 100 \%, 110 \%)$.

Table 3 Standard methods and apparatus for biodiesel characterization (Reproduced with permission from Pandey et al. 2013; Karmakar et al. 2018)

\begin{tabular}{llll}
\hline No. & Fuel property & Testing apparatus & Standard \\
\hline 1 & Acid number & Burette and pipette (titrimetric method) & - \\
2 & Calorific value & Digital bomb calorimeter & IS: 1448 [P: 6]: 1984 \\
3 & Kinematic viscosity & Redwood viscometer & IS: 1448 [P: 25] 1976 \\
4 & Relative density & Pycnometer & IS: 1448 [P: 32]: 1992 \\
5 & Flash and fire point & Flash and fire point apparatus & IS: 1448 [P: 32]: 1992 \\
6 & Cloud and pour point & Cloud and pour point apparatus & IS: 1448 [P: 10]: 1970 \\
7 & Ash content & Muffle furnace & ASTM D482-IP 4 of Institute of Petroleum \\
8 & Carbon residue & Carbon residue content apparatus & ASTM D189-IP 13 of Institute of Petroleum \\
\hline
\end{tabular}


Table 4 Details of the CI engine used to test the emission characteristics of the algal biodiesel

\begin{tabular}{ll}
\hline Maker & Kirloskar \\
Model & AV1 \\
Rated brake power, bhp/kW & $5 / 3.73$ \\
Rated speed, rpm & 1500 \\
Number of cylinder & 1 \\
Bore X stroke, mm & $80 \times 110$ \\
Displacement, cc & 552.920 \\
Compression ratio & $16.5: 1$ \\
Cooling system & Water cooled \\
Lubrication system & Forced feed \\
Standard injection timing & $27^{\circ}$ BTDC \\
\hline
\end{tabular}

\section{Result and discussion}

\subsection{Biodiesel properties}

All the properties of the algal biodiesel were within the ASTM standard limits (Table 5). The acid number of the algal biodiesel $(0.497 \mathrm{mg} \mathrm{KOH} / \mathrm{g}$ ) (Fig. 3a) was a little higher than that of petro-diesel (0.35) (Singh and Padhi 2009), but it does not harm the engine parts. The calorific value (CV) of any fuel plays an important role as higher calorific value indicates higher power generation to run an engine. Although the calorific value of the biodiesel produced in this experiment was lower $(40,666 \mathrm{~kJ} / \mathrm{kg})$ (Fig. 3b) than that of petrol or diesel, it was higher than the CVs of coal or popular biodiesels like palm and Jatropha (Fig. 2). Both viscosity and density of the algal biodiesel $\left(3.16 \mathrm{~mm}^{2} / \mathrm{s}\right.$ and $880.5 \mathrm{~kg} / \mathrm{m}^{3}$, respectively) (Fig. 3c, d) were almost equal to those of petro-diesel $\left(1.9-4.1 \mathrm{~mm}^{2} / \mathrm{s}\right.$ (Knothe and Steidley 2005) and $832 \mathrm{~kg} / \mathrm{m}^{3}$, respectively) which indicates good atomization and complete combustion of the biodiesel inside the engine and a healthier engine life. The flash and fire points of the biodiesel were much higher (150 and $153{ }^{\circ} \mathrm{C}$, respectively) (Fig. 3e), and thus better, than those of petro-diesel (flash point $93{ }^{\circ} \mathrm{C}$ and fire point $102{ }^{\circ} \mathrm{C}$ ) because higher flash and fire points reduce the chance of unexpected fire hazard. On contrary, the cloud and pour points of the produced fuel were higher (1 and $-2.67{ }^{\circ} \mathrm{C}$, respectively) (Fig. 3f) than those of diesel, though these were less than those of other biodiesels. So for these cold flow properties, algal biodiesel produced in this procedure can be used in cold atmospheric conditions. Biodiesel additives may be required if the temperature of the atmosphere is below $0{ }^{\circ} \mathrm{C}$. Lower ash

Table 5 Properties of algal biodiesel and their corresponding limits provided by ASTM

\begin{tabular}{llll}
\hline No. & Fuel property & Algal biodiesel & ASTM standards \\
\hline 1 & Acid number, $\mathrm{mg} \mathrm{KOH} / \mathrm{g}$ & 0.50 & 0.50 (maximum) \\
2 & Calorific value, $\mathrm{kJ} / \mathrm{kg}$ & 40,666 & - \\
3 & Kinematic viscosity at $40{ }^{\circ} \mathrm{C}, \mathrm{mm}^{2} / \mathrm{s}$ & 3.16 & $1.9-6$ \\
4 & Relative density at $15{ }^{\circ} \mathrm{C}, \mathrm{kg} / \mathrm{m}^{3}$ & 880.5 & $860-900$ \\
5 & Flash point, ${ }^{\circ} \mathrm{C}$ & 150 & 93 (minimum) \\
6 & Fire point, ${ }^{\circ} \mathrm{C}$ & 153 & - \\
7 & Cloud point, ${ }^{\circ} \mathrm{C}$ & 1 & 3 (maximum) \\
8 & Pour point, ${ }^{\circ} \mathrm{C}$ & -2.7 & - \\
9 & Ash content, $\%$ & 0.01 & 0.01 (maximum) \\
10 & Carbon residue, $\%$ & 0.037 & 0.50 (maximum) \\
\hline
\end{tabular}

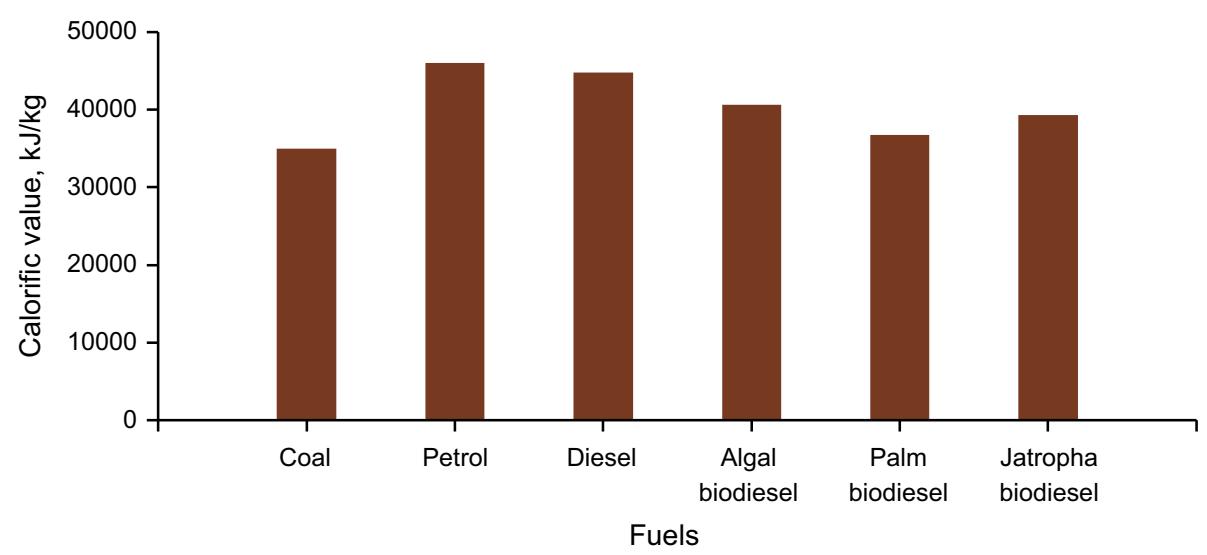

Fig. 2 Different fuels and their calorific values 

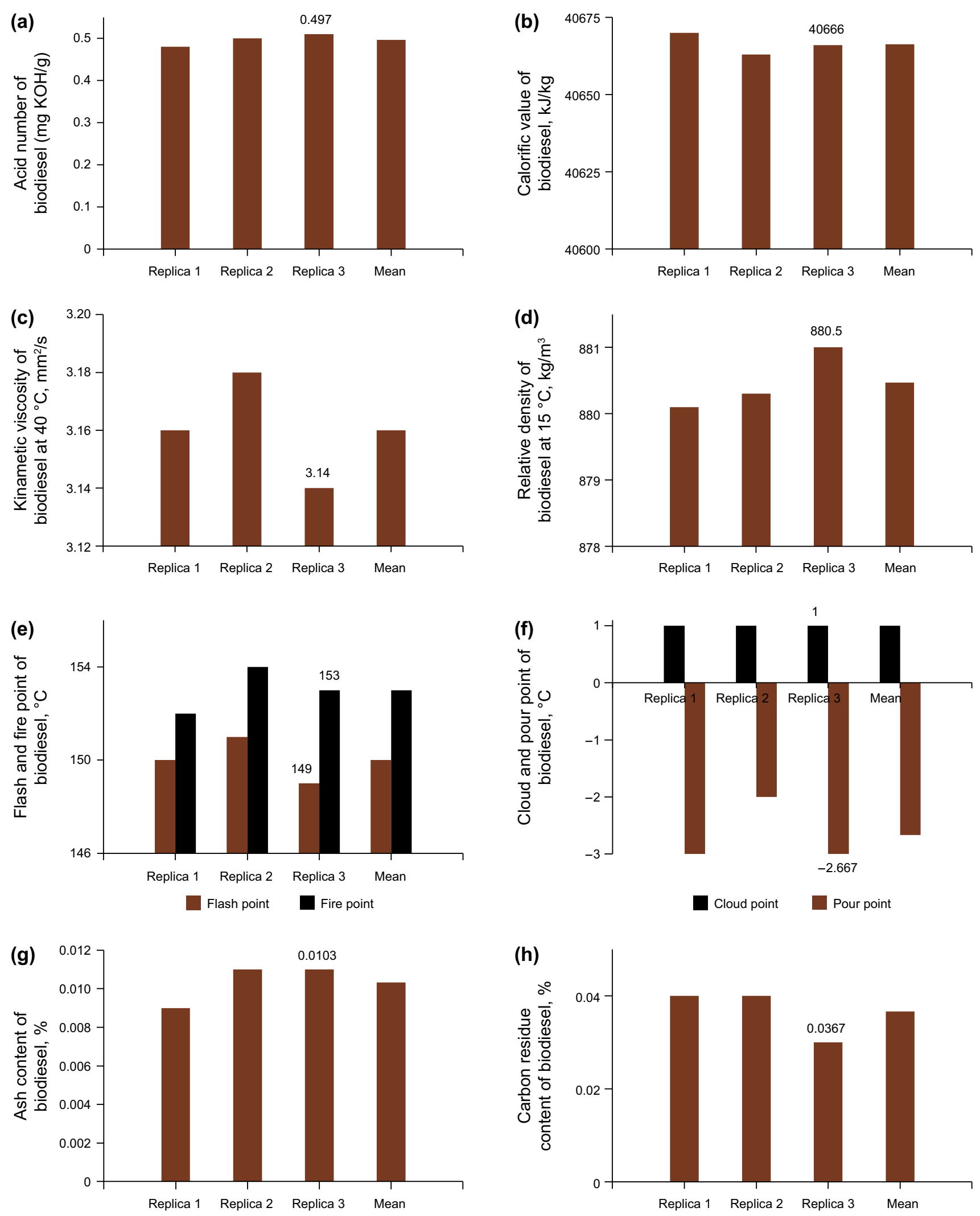

Fig. 3 Values (three replica of each experiment and their mean) of different properties of algal biodiesel—a acid value; $\mathbf{b}$ calorific value; $\mathbf{c}$ kinematic viscosity; $\mathbf{d}$ relative density; $\mathbf{e}$ flash and fire point; $\mathbf{f}$ cloud and pour point; $\mathbf{g}$ ash content; $\mathbf{h}$ carbon residue content 
content and carbon residue content produce lower deposition of carbon on engine parts and increases the engine life. The ash content of the algal biodiesel produced here was $0.01 \%$ (Fig. 3g), and the carbon residue content was $0.04 \%$ (Fig. 3h). So both the last two properties of the algal biodiesel were also low enough that the biodiesel can be used in an unmodified CI engine.

\subsection{Emission characteristics of algal biodiesel}

\subsubsection{Carbon monoxide (CO) emission}

According to some researchers, any increase in engine load fosters a decrease in fuel to air ratio inside the engine. This results in better combustion of the fuel and reduces the production of $\mathrm{CO}$. As the biodiesel contains in-built oxygen, combustion of it is more complete than petro-diesel. Hence, CO emission for combustion of biodiesel is lower than that of diesel. In this experiment, increased engine load was found to be associated with a gradual decrease in $\mathrm{CO}$ emission, and $\mathrm{CO}$ emission of algal biodiesel (191-30 ppm) was much lower than that of petro-diesel (560-101 ppm) (Fig. 4). The trend of CO emission in the present study is in line with similar research done with biodiesel from waste cooking oil (An et al. 2012).

\subsubsection{Carbon dioxide $\left(\mathrm{CO}_{2}\right)$ emission}

In CI engines, a more air-rich mixture is injected into the combustion chamber as the engine load increases. So, in a CI engine, the combustion of the fuel gets better with an increase in engine load. Hence, the pattern of emission of carbon dioxide from a $\mathrm{CI}$ engine is inverse to the pattern of emission of carbon monoxide, i.e. $\mathrm{CO}_{2}$ emission increases with an increase in engine load. In this experiment, a

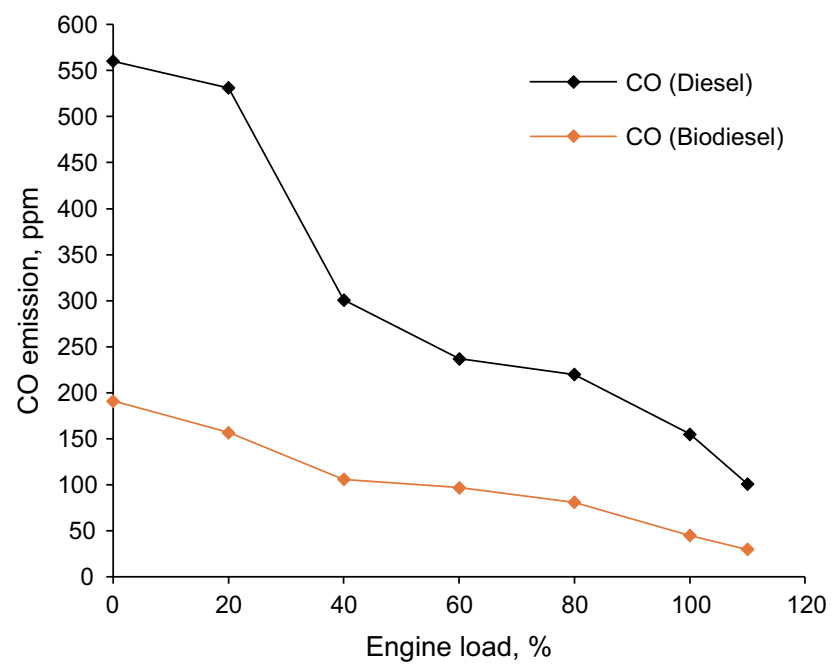

Fig. 4 Emission of $\mathrm{CO}$ with different engine loads gradual increase in $\mathrm{CO}_{2}$ emission was observed. $\mathrm{CO}_{2}$ emission for the combustion of algal biodiesel was lowest at zero load condition, and peak emission was observed to take place at overload condition in both the cases of diesel (2.9\% and $4.3 \%$, respectively) and algal biodiesel (2.7\% and $4.1 \%$, respectively) (Fig. 5). But at all load conditions of engine, emission of $\mathrm{CO}_{2}$ by biodiesel was less than that of diesel. As biodiesel has lower carbon-to-hydrogen ratio compared to diesel, $\mathrm{CO}_{2}$ emission is higher for combustion of the latter (Xue et al. 2011).

\subsubsection{Emission of nitrogen oxides $\left(\mathrm{NO}_{x}\right)$}

Under higher load, more heat is generated in the combustion chamber. This is why $\mathrm{NO}_{x}$ emission increases rapidly with an increase in engine load (Raheman and Ghadge 2007; Zhu et al. 2010). In the current experiment, $\mathrm{NO}_{x}$ emission was found to increase with the engine load for combustion of both diesel and biodiesel (Fig. 6). The emission was more in case of algal biodiesel (increased from 48 to $273 \mathrm{ppm}$ ) compared to petro-diesel (increased from 20 to $154 \mathrm{ppm}$ ) at all the engine load conditions. This may be because the in-built oxygen of biodiesel enhances formation of nitrogen oxides. Another reason for such emission behaviour might be the cylinder temperature of the engine. From Fig. 8, it can be seen that a higher exhaust temperature was generated when biodiesel was combusted. So, it can be assumed that the cylinder temperature would also be higher when the engine would be run by biodiesel. Therefore, more $\mathrm{NO}_{x}$ is produced from the combustion of algal biodiesel than from the combustion of petro-diesel. Emission of $\mathrm{NO}_{x}$ can be reduced by adding favourable additives to the algal biodiesel (Palash et al. 2014) or by

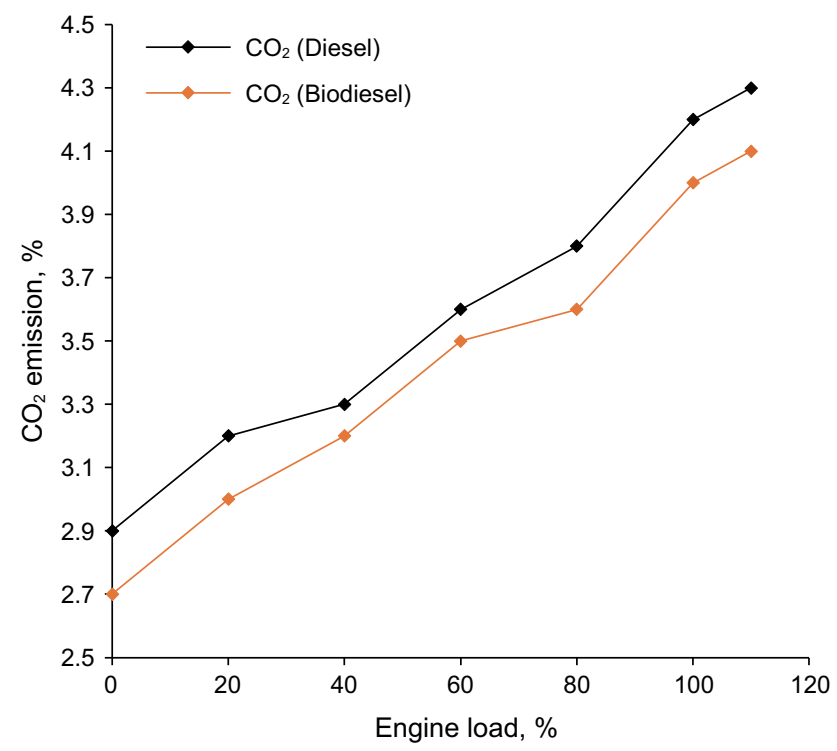

Fig. 5 Emission of $\mathrm{CO}_{2}$ with different engine loads 


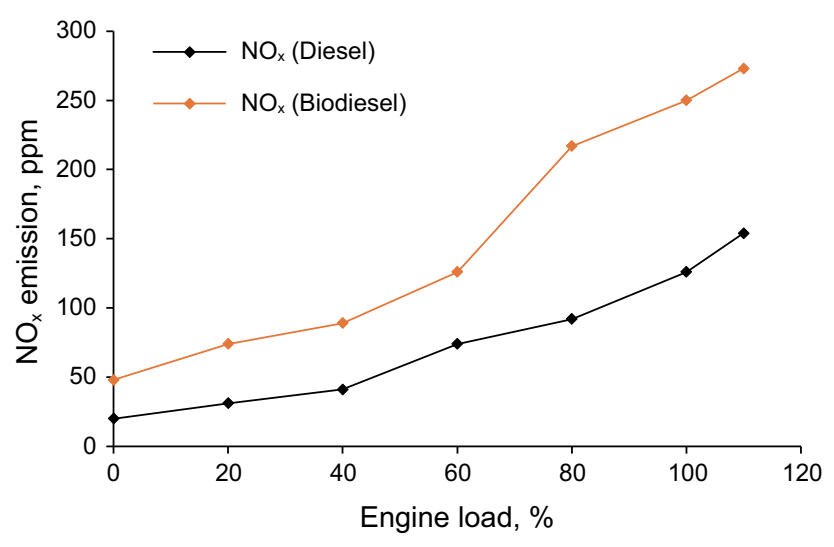

Fig. 6 Emission of $\mathrm{NO}_{x}$ with different engine loads

placing a catalytic converter (Zukerman et al. 2009) or a de- $\mathrm{NO}_{x}$ catalyser (Madia et al. 2002) in the exhaust manifold of a CI engine.

\subsubsection{Emission of unburned hydrocarbon (HC)}

Emission of unburned hydrocarbon takes place due to incomplete combustion of the fuel in the engine. So, HC emission for combustion of biodiesel must be less than petro-diesel because of the presence of in-built oxygen which triggers better combustion of the former. Here also, $\mathrm{HC}$ emission, under all load conditions, was less for algal biodiesel than that for diesel (Fig. 7). Emission of HC by diesel was found to decrease (from 38.9 to $25.7 \mathrm{ppm}$ ) with

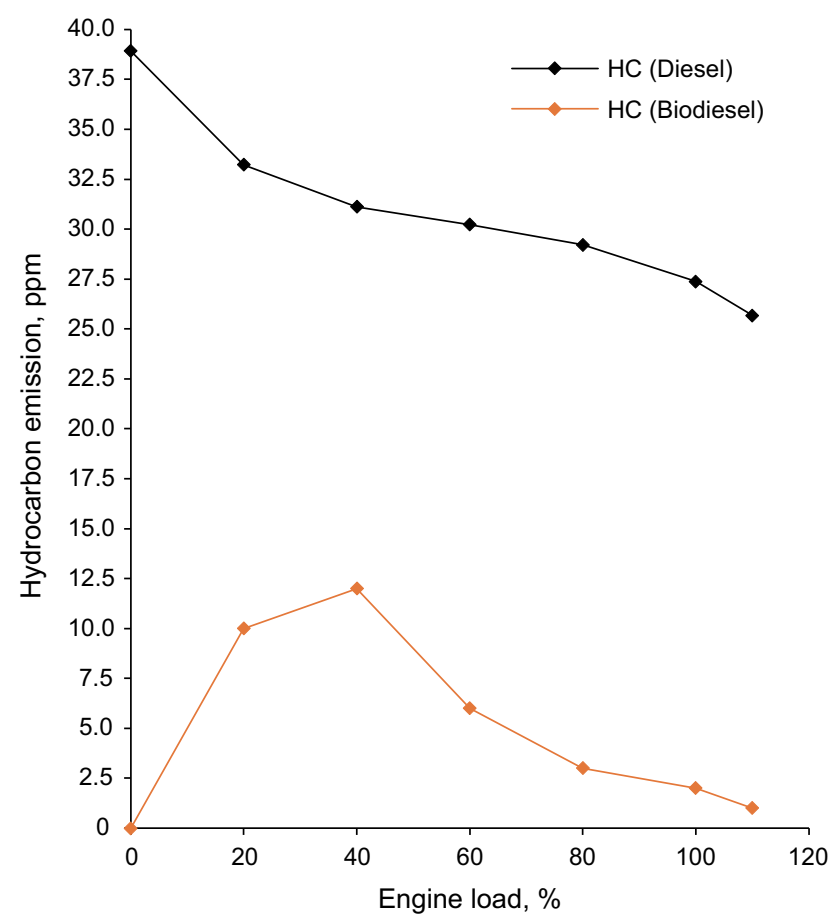

Fig. 7 Emission of hydrocarbon with different engine loads an increase in engine load. On contrary, emission of $\mathrm{HC}$, by algal biodiesel, started increasing at the outset of the experiment (from $0 \mathrm{ppm}$ at $0 \%$ load condition) and reached its peak (12 ppm) at $40 \%$ load and then decreased gradually up to the overload condition. According to the report of Shirneshan (2013), highest HC emission, for the combustion of waste frying oil methyl ester, takes place at $40 \%$ load and decreases gradually thereafter with the increase in engine load. This may take place because of the higher density of biodiesel than petro-diesel which results in bigger droplet size during atomization of the fuel in the engine. This bigger droplet size does not allow the fuel to burn completely, and as a result, $\mathrm{HC}$ emission increases. But as the load on engine increases, a more air-rich mixture (higher air to fuel ratio) is injected in the combustion chamber along with more fuel. For the presence of more air and more in-built oxygen of the biodiesel, better combustion takes place and emission of unburned $\mathrm{HC}$ reduces.

\subsubsection{Exhaust temperature}

Exhaust temperature is an important feature which should be kept in account as any increase of it affects the temperature of the surrounding environment. This may exert good or bad effect on the flora or fauna of that habitat. Exhaust temperature also gives an idea of the temperature inside the engine, and engine temperature plays a very important role in emission of different gases. In the current study, exhaust temperature was found to be higher for combustion of algal biodiesel than that for combustion of the diesel (Fig. 8) and in both the cases the temperature was found to increase $\left(41.2-59.7{ }^{\circ} \mathrm{C}\right.$ for diesel and $54.3-79.9{ }^{\circ} \mathrm{C}$ ) rapidly with an increase in engine load.

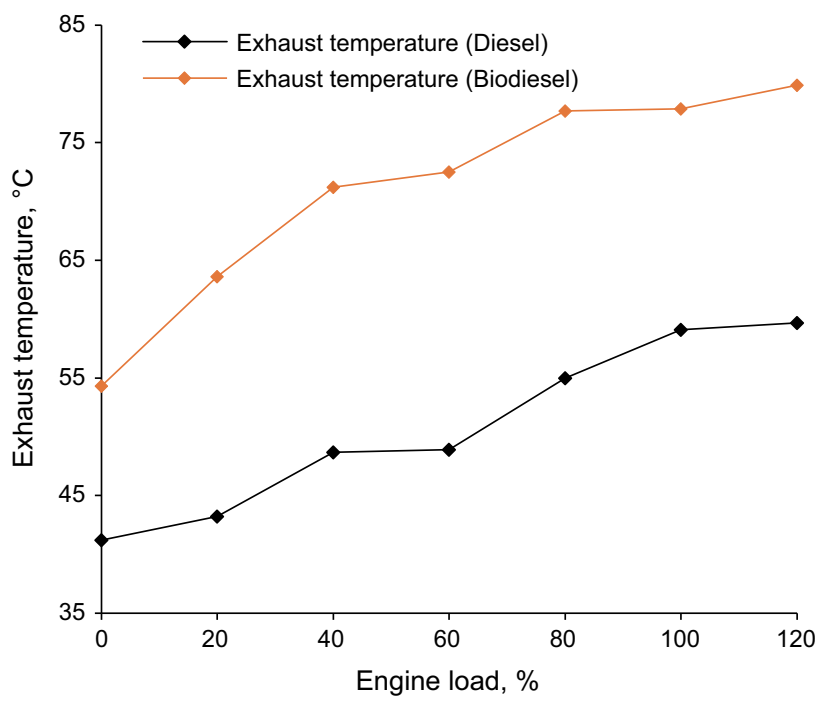

Fig. 8 Change in exhaust temperature with engine load 


\section{Conclusion}

Continuous supply of diesel or its substitutes has become very important over the last few decades due to rapid industrialization and urbanization all over the globe. Depletion of crude petroleum may result in huge scarcity of this fuel future. The market price of petro-diesel is also increasing for the same reason. So, biodiesel from unused algae might be one solution to the problem as the raw material, for this fuel has no commercial value. Although the algae oil produced in this experiment has a very high FFA content, biodiesel can be produced from it by a twostep procedure. All the properties of this biodiesel were found to be within the limits of ASTM standards. So, no engine modification should be required if diesel-biodiesel blend (with lower per cent of biodiesel) is used. More study is required on engine parts to use pure biodiesel (B100) which is used in $\mathrm{CI}$ engines. The high calorific value of this biodiesel indicates that high power would be generated in the engine. This would help to run the engine with less fuel. It was found that only $\mathrm{NO}_{x}$ emission for combustion of this biodiesel is higher than that of diesel, whereas emission of other gases like $\mathrm{CO}, \mathrm{CO}_{2}$ along with unburned hydrocarbon, can be reduced many fold if this biodiesel is used instead of petro-diesel.

Open Access This article is distributed under the terms of the Creative Commons Attribution 4.0 International License (http://creative commons.org/licenses/by/4.0/), which permits unrestricted use, distribution, and reproduction in any medium, provided you give appropriate credit to the original author(s) and the source, provide a link to the Creative Commons license, and indicate if changes were made.

\section{References}

Adewale P, Dumont M, Ngadi M. Recent trends of biodiesel production from animal fat wastes and associated production techniques. Renew Sustain Rev. 2015;45:574-88. https://doi.org/ 10.1016/j.rser.2015.02.039.

Alcantara R, Amores J, Canoira L, Fidalgo E, Franco MJ, Navarro A. Catalytic production of biodiesel from soy-bean oil, used frying oil and tallow. Biomass Bioenergy. 2000;18(6):515-27. https:// doi.org/10.1016/s0961-9534(00)00014-3.

Amano-Boadu V, Pfromm PH, Nelson R. Economic feasibility of algal biodiesel under alternative public policies. Renew Energy. 2014;67:136-42. https://doi.org/10.1016/j.renene.2013.11.029.

An H, Yang WM, Chou SK, Chua KJ. Combustion and emission characteristics of diesel engine fuelled by biodiesel at partial load conditions. Appl Energy. 2012;99:363-71. https://doi.org/ 10.1016/j.apenergy.2012.05.049.

Ashokkumar V, Agila E, Salam Z, Ponraj M, Md Din MF, Ani FN. A study on large scale cultivation of Microsystis aeruginosa under open raceway pond at semi-continuous mode for biodiesel production. Bioresour Technol. 2014;172:186-93. https://doi. org/10.1016/j.biortech.2014.08.100.
Bankovic-llic IB, Stojjkovic IJ, Stamenkovic OS, Veljkovic VB, Hung Y. Waste animal fats as feedstocks for biodiesel production. Renew Sustain Rev. 2014;32:238-54. https://doi.org/10. 1016/j.rser.2014.01.038.

Buasri A, Chaiyut N, Katlekha P, Mongkolwatee W, Boonrawd S. Biodiesel production from crude palm oil with a high content of free fatty acids and fuel properties. Chiang Mai Univ J Nat Sci. 2009;8:115-24.

Chisti Y. Biodiesel from microalgae. Biotechnol Adv. 2007;25(3):294-306. https://doi.org/10.1016/j.biotechadv.2007. 02.001 .

Chisti Y. Biodiesel from microalgae beats bioethanol. Trends Biotechnol. 2008;26(3):126-31. https://doi.org/10.1016/j.tib tech.2007.12.002.

Conti J, Holtberg P. International Energy Outlook 2011. Technology Report, www.eia.gov.

Costa JAV, Moraise MG. The role of biochemical engineering in the production of biofuels from microalgae. Bioresour Technol. 2011;102(1):2-9. https://doi.org/10.1016/j.biortech.2010.06.014.

Dassey AJ, Hall SG, Theegla CS. An analysis of energy consumption for algal biodiesel production: comparing the literature with current estimates. Algal Res. 2014;4:89-95. https://doi.org/10. 1016/j.algal.2013.12.006.

Fernandez CM, Ramos MJ, Perez A, Rodriguez JF. Production of biodiesel from winery waste: extraction refining and transesterification of grape seed oil. Bioresour Technol. 2010;101(18):7019-24. https://doi.org/10.1016/j.biortech.2010. 04.014 .

Gadge SV, Raheman H. Process optimization for biodiesel production from mahua (Madhuca indicia) oil for using response surface methodology. Bioresour Technol. 2005;97(3):379-84. https:// doi.org/10.1016/j.biortech.2005.03.014.

Holbrook GP, Davidson Z, Tatara RA, Ziemer NL, Rosentrater KA. Grayburn WS. Use of microalga Monoraphidium sp. grown in waste water as a feedstock for biodiesel: cultivation and fuel characterization. Appl Energy. 2014;131:386-93. https://doi.org/ 10.1016/j.apenergy.2014.06.043.

Karmakar R, Rajor A, Kundu K, Kumar N. Production of biodiesel from unused algal biomass in Punjab, India. Pet Sci. 2018. https://doi.org/10.1007/s12182-017-0203-0.

Knothe G, Steidley KR. Kinematic viscosity of biodiesel fuel components and related compounds. Influence of compound structure and comparison to petrodiesel fuel components. Fuel. 2005;84(9):1059-65. https://doi.org/10.1016/j.fuel.2005.01.016.

Kumar N, Mohapatra SK, Kundu K, Karmakar R. Optimization of safflower oil transesterification using the Taguchi approach. Pet Sci. 2017;14(4):798-805. https://doi.org/10.1007/s12182-0170183-0.

Madia G, Koebel M, Elsener M, Wokaun A. The effect of an oxidation precatalyst on the NOx reduction by ammonia SCR. Ind Eng Chem Res. 2002;41(15):3512-7. https://doi.org/10. 1021/ie0200555.

Palash SM, Kalam MA, Masjuki HH, Arbab MI, Masum BM, Sanjid A. Impacts of $\mathrm{NO}_{x}$ reducing antioxidant additive on performance and emissions of a multi-cylinder diesel engine fueled with Jatropha biodiesel blends. Energy Convers Manage. 2014;77:577-85. https://doi.org/10.1016/j.enconman.2013.10. 016.

Pandey RK, Rai A, Kundu K, Karmakar R, Roy P, Roy Chowdhury $A$, et al. Effect of process parameters for standardization of esterification of cotton seed oil for the production of biodiesel. Int J Curr Sci. 2013;8:74-8.

Ponnusamy S, Reddy HK, Muppaneni T, Downes CM, Deng S. Life cycle assessment of biodiesel production from algal bio-crude oils extracted under subcritical water conditions. Bioresour 
Technol. 2014;170:454-61. https://doi.org/10.1016/j.biortech. 2014.07.072.

Ragit SS, Mohapatra SK, Kundu K, Gill P. Optimization of neem methyl ester from transesterification process and fuel characterization as a diesel substitute. Biomass Bioenergy. 2011;35(3): 1138-44. https://doi.org/10.1016/j.biombioe.2010.12.004.

Ragit SS, Mohapatra SK, Gill P, Kundu K. Brown hemp methyl ester: transesterification process and evaluation of fuel properties. Biomass Bioenergy. 2012;41:14-20. https://doi.org/10.1016/j. biombioe.2011.12.026.

Raheman H, Ghadge SV. Performance of compression ignition engine with mahua (Madhuca indica) biodiesel. Fuel. 2007;86(16): 2568-73. https://doi.org/10.1016/j.fuel.2007.02.019.

Ross PJ. Taguchi techniques for quality engineering. New York: McGraw Hill Book Company; 1989. https://doi.org/10.1002/qre. 4680050312

Shirneshan A. HC, $\mathrm{CO}, \mathrm{CO}_{2}$, and $\mathrm{NO}_{\mathrm{x}}$ emission evaluation of a diesel engine fuelled with waste frying oil methyl ester. Proc Soc Behav Sci. 2013;75:292-7. https://doi.org/10.1016/j.sbspro. 2013.04.033.

Shirneshan A, Almassi M, Ghobadian B, Borghei AM, Najjafi GH. Effects of biodiesel and engine load on some emission characteristics of a direct injection diesel engine. Curr World Environ. 2012;7(2):207-12. https://doi.org/10.12944/cwe.7.2.03.
Silva PT, Detmann E, Valadares Filho SC, Detmann KSC, Barros LV, Martins SCV, et al. Evaluation of total and non-fatty ether extract in feeds and cattle feces using two analytical methods. Anim Feed Sci Technol. 2011;163:111-7. https://doi.org/10. 1016/j.anifeedsci.2010.10.012.

Singh RK, Padhi SK. Characterization of jatropha oil for the preparation of biodiesel. Nat Prod Radiance. 2009;8(2):127-32.

Sumit DH, Kumar T, Halder G. Biodiesel synthesis from Hevea brasiliensis oil employing carbon supported heterogeneous catalyst: Optimization by Taguchi method. Renew Energy. 2016;89:506-14. https://doi.org/10.1016/j.renene.2015.12.027.

Xue J, Grift TE, Hansen AC. Effect of biodiesel on engine performances and emissions. Renew Sustain Energy Rev. 2011;15(2):1098-116. https://doi.org/10.1016/j.rser.2010.11.016.

Zhu L, Zhang W, Liu W, Huang Z. Experimental study on particulate and $\mathrm{NO}_{x}$ emission of a diesel engine fuelled with ultra-low sulphur diesel, RME diesel blends and PME diesel blends. Sci Total Environ. 2010;408(5):1050-8. https://doi.org/10.1016/j. scitotenv.2009.10.056.

Zukerman R, Vradmana L, Herskowitza M, Livertsa E, Livertsa M, Massnerb A, et al. Modeling and simulation of a smart catalytic converter combining $\mathrm{NO}_{x}$ storage, ammonia production and SCR. Chem Eng J. 2009;155(1-2):419-26. https://doi.org/10. 1016/j.cej.2009.08.015. 